https://helda.helsinki.fi

\title{
Legal outcomes of all suspected neonaticides in Finland 1980-2000
}

\section{Putkonen, Hanna}

2007

Putkonen , H , Collander , J, Weizmann-Henelius , G \& Eronen , M 2007 , ' Legal outcomes of all suspected neonaticides in Finland 1980-2000 ' , International Journal of Law and Psychiatry , vol. 30 , no. 3 , pp. 248-254 . https://doi.org/10.1016/j.ijlp.2007.03.008

http://hdl.handle.net/10138/297729

https://doi.org/10.1016/j.ijlp.2007.03.008

publishedVersion

Downloaded from Helda, University of Helsinki institutional repository.

This is an electronic reprint of the original article.

This reprint may differ from the original in pagination and typographic detail.

Please cite the original version. 


\title{
Legal outcomes of all suspected neonaticides in Finland 1980-2000
}

\author{
Hanna Putkonen ${ }^{\mathrm{a}, \mathrm{b}, *}$, Jutta Collander ${ }^{\mathrm{a}}$, Ghitta Weizmann-Henelius ${ }^{\mathrm{a}}$, Markku Eronen ${ }^{\mathrm{a}}$ \\ a Vanha Vaasa Hospital, PO Box 13, 65381 Vaasa, Finland \\ b Department of Forensic Psychiatry, Helsinki University Central Hospital, PO Box 590, 00029 HUS, Finland
}

\begin{abstract}
This nationwide study examined legal outcomes and possible psychiatric diagnoses of suspected cases of neonaticide. Neonaticide is commonly defined as the killing of a newborn on the day of its birth, and is considered to have not only a low prevalence but also a high level of concealed criminality. This hidden nature guided us to find out what the final legal outcomes of suspected neonaticide were. It was a comprehensive, retrospective, register-based study of all 44 cases of suspected neonaticide that occurred 1980-2000 as recorded by Statistics Finland. The 44 cases were ascribed to 40 suspects, three of whom died themselves during the offence. Twelve cases (27\%) were eventually prosecuted and the accused convicted of neonaticide. Their mean sentence was 617 days (SD 216, range 300-1095 days). Fourteen offenders (35\% of offenders) underwent a forensic psychiatric examination, out of which four (29\%) were diagnosed with a psychotic disorder and $10(71 \%)$ with a personality disorder. Six of the 14 women were not sentenced as criminally irresponsible and three of them were committed to involuntary hospital care. Nine cases $(20 \%$ of cases) were still unsolved, and in eight (18\%) cases the offence title had changed into something other than neonaticide. We concluded that since only $41 \%$ of suspected neonaticides completed the court process as neonaticides, the previous results from studies on neonaticide may present a subgroup of offenders, not the whole picture. Therefore, further discussion and research is needed to elucidate this perplexing, sad, and utterly redundant offence in modern society, to prevent it, and develop treatment programs for the offenders.
\end{abstract}

(C) 2007 Elsevier Inc. All rights reserved.

\section{Introduction}

\subsection{Definitions}

Neonaticide is most commonly defined as the homicide of a newborn within its first $24 \mathrm{~h}$ of life. It is a subgroup of the more general term infanticide - the homicide of an infant of under a year of age. Detailed legislation of neonaticide varies among different countries. England and Canada hand down more lenient penalties for infanticide and neonaticide than for adult murders, but in the United States no such distinction is made (Kaye, Borenstein, \& Donnelly, 1990; Macfarlane, 2003). In Finland, legislation is not based on common law, as are the legal systems of, for example, the United Kingdom and the United States. Finnish legislation states the following: The crime committed by a woman who in a postpartum state of exhaustion or anxiety kills her child will be ruled a neonaticide, and she will be subject to

\footnotetext{
* Corresponding author. Vanha Vaasa Hospital, PO Box 13, 65381 Vaasa, Finland. Tel.: +358 9 4711; fax: +358 63567047.

E-mail address: hanna.putkonen@hus.fi (H. Putkonen).
} 
not less than 4 months and not more than 4 years of imprisonment ${ }^{1}$. Attempted neonaticide is criminalised as well. Moreover, legislative definitions of paternal neonaticide differ from country to country. It is not covered in Finnish legislation; only the mother can be convicted of neonaticide. Hence, if the father kills his newborn, he will be accused of manslaughter.

\subsection{Incidence and the general picture of neonaticide}

Only a few neonaticides are reported in each country annually, not only suggesting a low prevalence but also concealed criminality (Marks \& Kumar, 1993; Mendlowicz, Rapaport, Mecler, Golshan, \& Moraes, 1998). In England and Wales, neonaticides constitute about a quarter of all infant homicides, i.e. homicides of children of an age less than 1 year (Marks, 1996). In USA, 5\% of infant homicides have occurred during the first day of life (Overpeck, Brenner, Trumble, Trifiletti, \& Berendes, 1998). In another American study of reported deaths among live born infants between 1985 and 2000, $0.002 \%$ of the infants were killed or abandoned by a parent, a rate of 2.1 per 100000 per year (HermanGiddens, Smith, Mittal, Carlson, \& Butts, 2003). It has been speculated that infanticides resulting from maternal behavior may be among the least well documented in the US (Overpeck, 2003). In Finland, Vanamo, Kauppi, Karkola, Merikanto, and Räsänen (2000) showed that between 1970 and 1994, neonaticides constituted 19\% of all child homicides, and almost $50 \%$ of infant homicides.

Neonaticide, and infanticide more generally, is not a random crime but has been deeply embedded in the society in which it occurs and has a history of provoking inconsistent societal responses (Oberman, 2003). The comparative rarity of neonaticide has limited possibilities of its research. Previous studies have usually been qualitative (Stanton, Simpson, \& Wouldes, 2000), case reports (Green \& Manohar, 1990) or review articles (Resnick, 1970; Pitt \& Bale, 1995). Typical features or risk factors of neonaticide have been considered to be: youth of the offenders and no prenatal care (Haapasalo \& Petäjä, 1999; Overpeck, 2003) and concealment and/or denial of pregnancy (Miller, 2003). Further, a systematic study, using a valid screening instrument, the Dissociative Experiences Scale, reconfirmed the widespread incidence of pregnancy denial and dissociative symptoms characteristic of neonaticides (Spinelli, 2001). Furthermore, while some studies have found neonaticide offenders to lack mental illness (Cheung, 1986), others have found personality disorders prevalent among neonaticide perpetrators (Putkonen, Collander, Honkasalo, \& Lönnqvist, 1998).

British studies on legal outcomes of neonaticides have revealed that fathers receive more severe sentences than mothers (Marks \& Kumar, 1993, 1996). The authors speculated that sentencing might be related to the gender of the perpetrator but that the more detailed picture needs further analysis. In fact, it has been proposed that a successful defence of neonaticide cases would result in acquittal, conviction for a lesser offence, or a verdict of not guilty by reason of insanity or guilty but mentally ill (Macfarlane, 2003).

To sum, scientific literature on neonaticide has shown it to be a secret and hidden crime; statistics may represent the tip of the iceberg since many such deaths are never registered in official records. Research thus far has studied legally verified cases of neonaticide - that top end of the phenomenon. Therefore, to see what lied beyond the official neonaticides, we examined all suspected — instead of verified - neonaticides in Finland between 1980 and 2000, their legal decisions, and the possible diagnoses of the forensic psychiatric examinations. What happens to the suspected cases within the juridical process?

\section{Data and methods}

\subsection{Study sample}

Between 1980 and 2000, out of a total of 1,316,801 births in Finland (Statistics Finland, 2004a), 50 cases of neonaticide were reported to the police (Statistics Finland, 2004b). Of the 50 suspected neonaticides, four had actually taken place before the initial year 1980, one was, in fact, attempted homicide and one lacked any documentation, leaving 44 cases of suspected neonaticide in this study. Three cases exceeded the designated time limit of $24 \mathrm{~h}$ but met similar qualitative content for neonaticides described in the literature. We therefore found the 24-hour limit arbitrary

\footnotetext{
${ }^{1}$ Penal code, 1889 and 578/1995. Ri 101. Chapter 21, 4§. Suomen laki I. [Finnish Law I], Helsinki: Talentum Media Oy \& Lakimiesliiton kustannus.
} 
Table 1

Legal outcomes of all suspected cases of neonaticide in Finland 1980-2000

\begin{tabular}{lll}
\hline Legal outcome & $N$ & $\%$ \\
\hline Prosecuted and sentenced & 12 & 27 \\
Unsolved, halted $_{\text {Offence title changed }}^{\text {a }}$ & 9 & 20 \\
Never prosecuted & 8 & 18 \\
Not sentenced as criminally not responsible & 7 & 16 \\
Acquitted & 6 & 14 \\
Total & 2 & 5 \\
\hline
\end{tabular}

${ }^{a}$ During proceedings, the court assessed the evidence for neonaticide insufficient and another charge was used, for example "concealing a body without burial".

and regarded them as neonaticides according to the Finnish legislation. Even one of these not completing the juridical process as neonaticide occurred within the first $48 \mathrm{~h}$.

\subsection{Procedure}

The present study was based on written material in the form of data obtained from police investigation records and court decisions, and in 14 cases, also from forensic psychiatric examination documents. The court decision and the police investigation records included the preliminary report, interrogation account of the suspect, the judicial decision in the matter, and other interrogations and documents, when available. The data was part of a larger study of Finnish female homicide offenders (Putkonen et al., 1998, 2001a; Putkonen, Komulainen, Virkkunen, \& Lonnqvist, 2001b; Putkonen, Komulainen, Virkkunen, Eronen, \& Lonnqvist, 2003).

In Finland, the court decides whether or not a forensic psychiatric examination is required to assess the criminal responsibility of the offender at the time of the offence, and most homicide offenders are examined. The forensic psychiatric examination is a hospital-based psychiatric study of the offender consisting of a collection of comprehensive medical and social data, psychological testing, physical examinations, and continuous observation. Diagnoses made during the examinations were based on ICD-8 (World Health Organization, 1967) and DSM-III (American Psychiatric Association, 1980) criteria before 1987, and on DSM-III-R (American Psychiatric Association, 1987) criteria thereafter. ICD-10 (World Health Organization, 1992) became the official classification in 1996. In addition, DSM-IV (American Psychiatric Association, 1994) has been widely used.

The variables used in the present study included previous criminality and possible death of the offender, factors associated with the legal outcome of all cases, and the criminal responsibility as well as psychiatric diagnoses and intelligence for the 14 women who underwent forensic psychiatric examination. The authors coded the variables into a SPSS 11.5 file. Ethical approval was received from the Ethics Committee of the University of Helsinki and the National Authority of Medicolegal Affairs.

\section{Results}

\subsection{Legal outcomes}

The 44 cases of suspected neonaticides between 1980 and 2000 were ascribed to 40 individual suspects since three women were suspected of having committed multiple neonaticides (two of two cases each, one of three). Four of these 40 women had offended previously (petty theft, driving while intoxicated and two unlawful uses of a vehicle). Of the 44 cases, 12 were eventually prosecuted and the offenders sentenced, while six were prosecuted but the offenders not held criminally responsible for neonaticide (Table 1$)$. Therefore, 18 cases $(41 \%)$ went through the complete trial process as neonaticides.

Of the 12 cases prosecuted and sentenced for neonaticide, ten offenders $(83 \%)$ received a sentence of conditional (suspended) imprisonment and two of unconditional imprisonment. The mean length of the sentences was 617 days (SD 216, range 300-1095 days).

If the pathological examination could not verify without a doubt that the newborn was alive with normal possibilities of life and that the death was intentionally caused, neonaticide charges were not forwarded. In eight cases 
Table 2

Psychiatric diagnoses of neonaticide offenders in forensic psychiatric examinations $(n=14)$

\begin{tabular}{lll}
\hline Diagnosis & $N$ & $\%$ \\
\hline Psychotic disorder $^{\text {a }}$ & 4 & 29 \\
Postpartum depressive psychosis & 3 & 21 \\
Unspecified psychosis & 1 & 7 \\
Personality disorder & 10 & 71 \\
PD $^{\mathrm{b}}$ not otherwise specified & 6 & 43 \\
Borderline PD $^{\mathrm{b}}$ & 4 & 29 \\
Substance use disorder $^{\mathrm{c}}$ & 1 & 7 \\
\hline
\end{tabular}

${ }^{a}$ Two were also diagnosed with a personality disorder.

b Personality disorder.

c Also diagnosed with a personality disorder.

the charge was revised: three into involuntary manslaughter, three into "concealing a body without burial", one into "unlawful disposal of a body", and one into manslaughter. Two of the above received no sentence, four were fined, one received a conditional (suspended) sentence of 7 months, and one 7 years 6 months imprisonment.

Of the nine cases still unsolved or halted as of this writing, three were ascribed to one woman. The bones of at least three burnt newborns were found in her home. She committed suicide before investigations could be completed. Two other bodies of infants were found in the forest; a psychotic woman was suspected of one but never accused, and no suspects were found to account for the other. One body was found in a dumping-ground, but there were no suspects. In the remaining three cases investigations were halted for lack of progress: one woman was suspected of two deaths, there was proof of pregnancies and delivery, and she admitted to three miscarriages, the bodies of which she had put into a bag and disposed of in a dumpster. Another woman was suspected of one case, denied it, and no progress could be made in the investigation. In addition to the above halted investigations, there were seven cases never prosecuted. Two women died immediately after the neonaticide. Both literally bled to death. Their husbands had found them bleeding severely but the women refused any help. When the ambulance finally arrived, it was too late. Later on, the infants were found in bags. The rest in the group of never prosecuted and the two cases acquitted did not produce enough evidence to be forwarded in the process as neonaticides. There were some inconsistencies regarding the handling of the cases. In one, pathological examination assessed homicide as the cause of death but the offender was acquitted, and in another, the offender admitted planning to kill the baby and she strangulated it and filled its mouth with cotton wool, but because it could not be verified that the baby did not die already during delivery, the perpetrator was acquitted.

\subsection{Forensic psychiatric examination}

In the current study of 40 alleged suspects of neonaticide, 14 (35\%) women underwent a forensic psychiatric examination. Two (14\%) of these were found criminally responsible, six (43\%) with diminished responsibility and six not criminally responsible. Three women (21\%) were found to be in need of involuntary hospital care. Of the four women with a psychotic disorder, two also had a personality disorder. When these latter two were only coded in the psychotic group, $29 \%$ of the examined women were psychotic and $71 \%$ personality disordered (Table 2 ). Three of the four psychotic women were diagnosed with psychotic depression regarded as postpartum psychosis. They had suffered from postpartum depression after their previous delivery and now their despair was psychotic leading to neonaticide. The third psychotic woman suffered from an organic type of psychosis, and she was mentally retarded. Of all the 14 women under observation for psychiatric problems, 12 (86\%) had at least average intelligence (IQ over 85).

\section{Discussion}

This was a nationwide, comprehensive study of all suspected cases of neonaticide in Finland between 1980 and 2000 with the aim to examine their legal outcomes and possible psychiatric diagnoses of the suspects. The results strengthened the view of neonaticide as a hidden crime since most (26/44,59\%) cases did not complete the court process as neonaticide and, therefore, were not represented in final official court statistics as such. Of the 12 who were sentenced, $83 \%$ received conditional (suspended) imprisonment. Therefore it seemed that in Finland, the handling of neonaticide cases and the sentences involved were lenient just as has been proposed as the best outcome (Macfarlane, 2003), and as is also common 
in some other countries (Marks \& Kumar, 1993, 1996). An interesting detail was that there were three women suspected of multiple neonaticides, a finding only seldom reported (Yamauchi, Usami, Ikeda, Echizen, \& Yoshioka, 2000).

Neonaticide is a problematic subject to study and has also produced relatively little case law (Macfarlane, 2003). The bodies of the newborns might never be found, neonaticide may be difficult to attribute with certainty to any one person, the perpetrator herself might have been in an abnormal state, and the pathological examinations of the newborn tend to be non-specific. Further, the cases are often classified under different charges or are altogether lost in statistics because of suicide, inadequate proof, and pre-trial plea-bargains. The results of the present study showed exactly how cases were "lost" with inconsistent outcomes. Similar cases fell under different categories, e.g. the death of an offender led to the category of unsolved crime in one case, and in two cases to "never prosecuted". Yet, legislative practice follows the well known saying - it is better to acquit 100 guilty persons than to convict one innocent one. The covert nature of this crime does make studies and consequently prevention difficult. It seems the studies on neonaticide offenders may, in fact, present a picture of a mere subgroup of offenders.

The Finnish police have a very high clearance rate for homicide; between 1992 and 2003 it was 93\% (Statistics Finland, 2004c). In the present study material, $80 \%$ of suspected neonaticide cases were cleared by the police. This $80 \%$ clearance rate is close to that of general violent offending since the beginning of the 1990's (The National Research Institute of Legal Policy, 2000). This emphasizes the specific nature of neonaticide as a form of covert homicide. Further, our results showed that only $35 \%$ of the suspected offenders underwent a forensic psychiatric examination. Of the 35 cases solved by the police, the percentage was 40 . In previous Finnish studies, $70-75 \%$ of accused offenders of homicides or attempted homicides have been committed into a pre-trial forensic psychiatric examination (Eronen, Hakola, \& Tiihonen, 1996; Putkonen et al., 2001b). Perhaps the already lenient legislation lowers the need for forensic psychiatric examinations or, perhaps, this reflects lower levels of mental illness among neonaticide perpetrators compared with other homicide offenders. Yet, in the present study, all the women in a forensic psychiatric examination did receive a psychiatric diagnosis and, furthermore, personality disorders prevailed, as expected based on some previous studies (Levene \& Bacon, 2004) but not on others (Cheung, 1986).

\subsection{Strengths and limitations}

Even though Finland is well-known for its tradition of well documented statistics, the present study design included both strengths and weaknesses. The study was nationwide, a definite strength. Further, police investigative material not yet argued in court proceedings was unique data. Yet, even with 21 years of data the complete number of cases was small limiting statistical analyses and conclusions. However, longer study periods would run the risk of invalidating conclusions more drastically with legislative, diagnostic and societal changes in time.

Results concerning psychiatric information were quite sparse. Verified psychiatric information was available only from the forensic psychiatric examination reports. All the diagnoses in the forensic psychiatric examinations were based on thorough clinical examinations, and if diagnostic criteria had not been fulfilled, no psychiatric diagnosis would have been made. The basic categories of psychotic and personality disorder can be assumed reliable and these reports have been used as study material before (Eronen, 1995, 1996; Putkonen et al., 2001a). Moreover, the information on legal decisions was explicit and not open to interpretations.

Despite the fact that the most common definition of neonaticide is based on the 24-hour rule, the study population included three cases in which the age of the newborn exceeded $24 \mathrm{~h}$. Two of them were even ruled neonaticides and the third occurred within the first $48 \mathrm{~h}$. Their inclusion supported a suggestion made by Kaye et al. (1990), that the "neonatal" period should be expanded to be consistent with biological and psychological determinants. They referred to The American Pediatric Association and The American College of Obstetrics and Gynecology which considers the neonatal period to extend beyond the first $24 \mathrm{~h}$ of life, lasting up to 3 months. Finnish legislation emphasises the context of neonaticide - it demands that the cause and effect relationship between the parturition and the child killing must be demonstrable and, therefore, time, in and of itself, has minor significance. Perhaps the scientific community should further discuss the definition of neonaticide.

\subsection{Concluding remarks}

If all originally reported 50 cases were classified as actual neonaticides, the rate for neonaticide would be $0.0038 \%$ of live born infants (Statistics Finland, 2004a), a rate of 0.18 per 100000 per year. If only the 18 cases that passed the 
whole juridical process as neonaticides were de facto neonaticides, the rate for neonaticides in Finland would be $0.001 \%$ of live born infants, a rate of 0.07 per 100000 per year. This is most probably a vast underestimation. The true incidence of neonaticide may never be known.

Due to the rare occurrence of neonaticides, there is no established pattern for investigating and trying the cases. Hence, everything during the legal process may vary starting from the pathological reports and, even the psychological and social aspects may be emphasised differently depending on the moral assumptions of the individual authorities involved. The jurisprudence with regard to child deaths is complicated, and perhaps current legal process is not the most suitable way to handle these cases; miscarriage of justice is a high risk (Levene \& Bacon, 2004). A good start would be to organize the neonaticide cases to specialized groups for both investigating and trying the cases to attain better consistency. At least the known cases would be better described and handled.

Only three of the 40 neonaticide offenders were committed to hospital care. It is highly doubtful that many of the other women received adequate treatment or counselling after the crime regardless of its legal decision. There were some reoffenders in our material and perhaps some special attention and treatment would be necessary to prevent reoffending. Furthermore, studies might focus on providing knowledge on the needs of the perpetrator prior to the neonaticide. In fact, the known neonatal women might be asked what kind of help they thought would have been needed before the index crime to have helped prevent it. Combining basic epidemiological methods with hearing the perpetrators themselves might capture practical means to prevent neonaticide, and might answer the wishes already presented for better prevention and identification of subgroups and risk factors of neonaticide (Spinelli, 2004; Friedman, McCue Horwitz, \& Resnick, 2005).

The moral and legal personhood of late-term foetuses and newborns is a topic of heated discussion even today; as a person in the fullest sense the newborn enjoys an undisputed and state-protected right to life (Gross, 2002). Even though neonaticide is not a frequent crime, it is the ethical outback of modern society. The weight of an ethical dilemma does not depend on the number of cases (Gross, 2002). Neonaticide is a phenomenon to be observed from more than the medical or juridical viewpoints. Hence a general discussion is welcome and, in fact, necessary. Even if it saves only one life.

\section{Acknowledgements}

We thank all the helpful people we worked with in the police departments, courts, Statistics Finland, the National Authority for Medicolegal Affairs, and within our own institutions.

\section{References}

American Psychiatric Association (1980). Diagnostic and Statistical Manual of Mental Disorders (3rd edn) (DSM-III). Washington, DC: American Psychiatric Association.

American Psychiatric Association (1987). Diagnostic and Statistical Manual of Mental Disorders (3rd edn, revised) (DSM-III-R). Washington, DC: American Psychiatric Association.

American Psychiatric Association (1994). Diagnostic and Statistical Manual of Mental Disorders (4th edn) (DSM-IV). Washington, DC: American Psychiatric Association.

Cheung, P. T. K. (1986). Maternal filicide in Hong Kong, 1971-1985. Medicine, Science and the Law, 26, $185-192$.

Eronen, M. (1995). Mental disorders and homicidal behaviour in female subjects. American Journal of Psychiatry, 152, 1216-1218.

Eronen, M., Hakola, P., \& Tiihonen, J. (1996). Mental disorders and homicidal behavior in Finland. Archives of General Psychiatry, 53, 497-501.

Friedman, S. H., McCue Horwitz, S., \& Resnick, P. J. (2005). Child murder by mothers: A critical analysis of the current state of knowledge and a research agenda. American Journal of Psychiatry, 162, 1578-1587.

Green, C. M., \& Manohar, S. V. (1990). Neonaticide and hysterical denial of pregnancy. British Journal of Psychiatry, 156, $121-123$.

Gross, M. L. (2002). Abortion and neonaticide: Ethics, practice and policy in four nations. Bioethics, 16, $202-230$.

Haapasalo, J., \& Petäjä, S. (1999). Mothers who killed or attempted to kill their child: Life circumstances, childhood abuse, and types of killing. Violence and Victims, 14, 219-239.

Herman-Giddens, M. E., Smith, J. B., Mittal, M., Carlson, M., \& Butts, J. D. (2003). Newborns killed or left to die by a parent: a population-based study. Journal of the American Medical Association, 289, 1425-1429.

Kaye, N. S., Borenstein, N. M., \& Donnelly, S. M. (1990). Families, murder, and insanity: A psychiatric review of paternal neonaticide. Journal of Forensic Science, 35, 133-139.

Levene, S., \& Bacon, C. J. (2004). Sudden unexpected death and covert homicide in infancy. Archives of Disease in Childhood, 89, $443-447$.

Macfarlane, J. (2003). Criminal defense in cases of infanticide and neonaticide. In M. G. Spinelli (Ed.), Infanticide: psychosocial and legal perspectives on mothers who kill (pp. 133-166). Washington, DC: American Psychiatric Publishing.

Marks, M. N. (1996). Characteristics and causes of infanticide in Britain. International Review of Psychiatry, 8, 99-107. 
Marks, M. N., \& Kumar, R. (1993). Infanticide in England and Wales. Medicine, Science and the Law, 33, 329-339.

Marks, M. N., \& Kumar, R. (1996). Infanticide in Scotland. Medicine, Science and the Law, 36, 299-305.

Mendlowicz, M. V., Rapaport, M. H., Mecler, K., Golshan, S., \& Moraes, T. M. (1998). A case-control study on the socio-demographic characteristics of 53 neonaticidal mothers. International Journal of Law and Psychiatry, 21, 209-219.

Miller, L. J. (2003). Denial of Pregnancy. In M. G. Spinelli (Ed.), Infanticide: Psychosocial and Legal Perspectives on Mothers who Kill (pp. 81-104) Washington, DC: American Psychiatric Publishing.

Oberman, M. (2003). A brief history of infanticide and the law. In M. G. Spinelli (Ed.), Infanticide: Psychosocial and legal perspectives on mothers who kill (pp. 3-18). Washington, DC: American Psychiatric Publishing.

Overpeck, M. (2003). Epidemiology of infanticide. In M. G. Spinelli (Ed.), Infanticide: Psychosocial and legal perspectives on mothers who kill (pp. 19-31). Washington, DC: American Psychiatric Publishing.

Overpeck, M. D., Brenner, R. A., Trumble, A. C., Trifiletti, L. B., \& Berendes, H. W. (1998). Risk factors for infant homicide in the United States New England Journal of Medicine, 339, 1211-1216.

Penal code 1889 and 578/1995. Ri 101. Chapter 21, 4§. Suomen laki I. [Finnish Law I], Helsinki: Talentum Media Oy \& Lakimiesliiton kustannus.

Pitt, S. E., \& Bale, E. M. (1995). Neonaticide, infanticide, and filicide: A review of the literature. Bulletin of the American Academy of Psychiatry and the Law, 23, 375-386.

Putkonen, H., Collander, J., Honkasalo, M. -L., \& Lönnqvist, J. (1998). Finnish female homicide offenders 1982-92. Journal of Forensic Psychiatry, 9, 672-683.

Putkonen, H., Collander, J., Honkasalo, M. -L., \& Lönnqvist, J. (2001). Personality disorders and psychoses form two distinct subgroups of homicide among female offenders. Journal of Forensic Psychiatry, 12, 300-312.

Putkonen, H., Komulainen, E. J., Virkkunen, M., \& Lönnqvist, J. (2001). Female homicide offenders have greatly increased mortality from unnatural deaths. Forensic Science International, 119, 221-224.

Putkonen, H., Komulainen, E. J., Virkkunen, M., Eronen, M., \& Lönnqvist, J. (2003). Risk of repeat offending among violent female offenders with psychotic and personality disorders. American Journal of Psychiatry, 160, 1-5.

Resnick, P. J. (1970). Murder of the newborn: A psychiatric review of neonaticide. American Journal of Psychiatry, 126, 1414-1420.

Spinelli, M. G. (2001). A systematic investigation of 16 cases of neonaticide. American Journal of Psychiatry, 158, 811-813.

Spinelli, M. G. (2004). Maternal infanticide associated with mental illness: Prevention and the promise of saved lives. American Journal of Psychiatry, 161, 1548-1557.

Stanton, J., Simpson, A., \& Wouldes, T. (2000). A qualitative study of filicide by mentally ill mothers. Child Abuse and Neglect, 24, 1451-1460.

Statistics Finland. (2004a). Väkiluku, syntyneet, kuolleet, solmitut avioliitot, avioerot, luonnollinen väestönkasvu, väestönkasvu ja kuntien välinen muuttolike vuosina 1749-2003. [Statistical information] Retrieved November 3, 2005, from http://pxweb2.stat.fi/Dialog/varval.asp? ma=vamuu_001_1980_001\&ti=V\%E4est\%F6nmuutokset+alueittain+1980\%2D2004\&path=../Database/V\%E4est\%F6/V\%E4est\%F6nmuutokset/\&lang=3

Statistics Finland. (2004b). Criminality 1980-2002. [Statistical information] Retrieved November 3, 2005, from http://statfin.stat.fi/statweb/start. asp?LA=fi\&lp=home

Statistics Finland. (2004c). Rikokset ja niiden selvittäm. 1980-. [Statistical information] Retrieved November 3, 2005 from http://statfin.stat.fi/ statweb/start.asp?LA =fi\&DM=SLFI\&lp=catalog\&clg=oikeus>

The National Research Institute of Legal Policy. (2000). Crime and Criminal Justice in Finland 1999. Helsinki 2000, Summary, Publication 175. http://www.om.fi/optula/7216.htm

Vanamo, T., Kauppi, A., Karkola, K., Merikanto, J., \& Räsänen, E. (2000). Intra-familial child homicide in Finland 1970-1994: Incidence, causes of death and demographic characteristics. Forensic Science International, 117, 199-204.

World Health Organization (1967). The ICD-8 Classification of Mental and Behavioural Disorders. Geneva: World Health Organization.

World Health Organization (1992). The ICD-10 Classification of Mental and Behavioural Disorders. Geneva: World Health Organization.

Yamauchi, M., Usami, S., Ikeda, R., Echizen, N., \& Yoshioka, N. (2000, Sep 11). Medico-legal studies on infanticide: statistics and a case of repeated neonaticide. Forensic Science International, 113(1-3), 205-208. 